\title{
The influence of selected fungicides used at different dates on residues in apples and protection against storage diseases
}

\author{
Wpływ wybranych fungicydów stosowanych w różnych terminach \\ na poziom ich pozostałości w jabłkach \\ oraz ochronę przed chorobami przechowalniczymi
}

\author{
Jolanta Szymczak, Hanna Bryk, Artur Miszczak
}

\begin{abstract}
Summary
The level of residues of active substances of the fungicides Captan 80 WG and Thiram Granuflo 80 WG applied in protection against apple storage diseases and their effectiveness were investigated. Captan 80 WG was used to protect against bull's eye rot of cultivar Szampion apples in 11 protection programs, in which it was applied from 1 to 4 treatments at various combinations of terms $(28,21,14,7$ days before harvest). Thiram Granuflo 80 WG was used against storage scab of cultivar Jonagored apples in 4 protection programs, in which the treatments were applied in terms: 14 and 7 days before harvest. Fruits from trees not treated with the fungicides were regard as the control. It was found, that double application of the Captan 80 WG in terms of 21 and 14 days before harvest was safe for captan residues in apples, and had a very good efficacy against bull's eye rot of apples. In turn, Thiram Granuflo 80 WG significantly restricted the storage scab after one application, only at low disease severity. However, when the infection was higher, significant effectiveness was obtained by double use of Thiram Granuflo 80 WG while the content of $\mathrm{CS}_{2}$, as dithiocarbamates indicator met the standard requirements.
\end{abstract}

Key words: residues of fungicides, apples, postharvest diseases

\section{Streszczenie}

Badano w jabłkach poziom pozostałości substancji czynnych preparatów Captan 80 WG i Thiram Granuflo 80 WG zastosowanych przed zbiorem $w$ różnych programach zwalczania chorób przechowalniczych oraz oceniano skuteczność tych programów. Captan 80 WG zastosowano na odmianie Szampion w 11 programach ochrony przed gorzką zgnilizną jabłek, w których wykonywano od 1 do 4 zabiegów w różnych kombinacjach terminów $(28,21,14,7$ dni przed zbiorem). Thiram Granuflo 80 WG zastosowano przeciwko parchowi przechowalniczemu na odmianie Jonagored w 4 programach, w których wykonywano zabiegi w terminach 14 i 7 dni przed zbiorem. Kontrolę stanowiły owoce $z$ drzew nieopryskiwanych w tych terminach żadnymi fungicydami. Stwierdzono, że dwukrotne zastosowanie Captanu 80 WG w terminach 21 i 14 dni przed zbiorem nie powodowało przekroczenia poziomu pozostałości kaptanu w jabłkach oraz bardzo dobrze chroniło jabłka przed gorzką zgnilizną. Z kolei Thiram Granuflo 80 WG istotnie ograniczał parcha przechowalniczego po jednokrotnym zastosowaniu, gdy nasilenie choroby było niewielkie. Natomiast, gdy zakażenie parchem było silniejsze istotną skuteczność w zwalczaniu uzyskano po dwukrotnym zastosowaniu środka Thiram Granuflo 80 WG, przy jednoczesnym spełnieniu norm na zawartość $\mathrm{CS}_{2}$ w jabłkach.

Słowa kluczowe: pozostałości fungicydów, jabłka, choroby przechowalnicze

\author{
$\overline{\text { Instytut Ogrodnictwa }}$ \\ Oddział Sadownictwa \\ Konstytucji 3 Maja 1/3, 96-100 Skierniewice \\ Jolanta.Szymczak@inhort.pl
}




\section{Wstęp / Introduction}

Stosowanie chemicznych środków ochrony roślin jest najbardziej efektywnym sposobem ochrony roślin sadowniczych przed chorobami, jednak wiąże się z ryzykiem wystapienia pozostałości pestycydów w owocach. Ocena pozostałości środków ochrony roślin w produktach spożywczych, w tym w owocach, jest w ostatnich latach przedmiotem szczególnego zainteresowania organów państwowych odpowiedzialnych za bezpieczeństwo żywności, które kontrolują dopuszczalne poziomy zawartości pestycydów. Monitorowanie pozostałości pestycydów w żywności ma na celu nie tylko sprawdzenie zgodności z najwyższymi dopuszczalnymi poziomami pozostałości (Rozporządzenie 2005, 2007) i prawidłowości użycia środków ochrony roślin (Rozporządzenie 2008), ale również ocenę narażenia konsumentów na pozostałości pestycydów (Ustawa 2006; Nowacka i Gnusowski 2009; Nowacka i wsp. 2012). Duże ryzyko obecności pestycydów w jabłkach stwarzają środki stosowane w okresie przedzbiorczym przeciwko chorobom przechowalniczym. Takie postępowanie jest obecnie koniecznością, bowiem choroby pochodzenia grzybowego mogą powodować bardzo duże straty, sięgające nawet $40 \%$ przechowywanych jabłek (Bryk 2010). Wśród tych chorób najczęściej występuje gorzka zgnilizna jabłek (Pezicula spp.), zarówno w Polsce (Bryk 2010), jak i w innych krajach europejskich (Neri i wsp. 2009; Weber 2009). Przeciwko tej chorobie wykonuje się w okresie przedzbiorczym kilka zabiegów fungicydami, w zależności od podatności odmiany jabłoni i panujących warunków atmosferycznych. Jednym ze środków polecanych do tego celu od wielu lat jest Captan 80 WG (Bryk 2003). Z powodu relatywnie niskiej ceny środka oraz trudności ze stosowaniem innych polecanych środków, Captan $80 \mathrm{WG}$ jest w wielu sadach kilkakrotnie używany przed zbiorem. Inną chorobą przechowalniczą, istotnie pogarszającą jakość jabłek, jest parch przechowalniczy (Venturia inaequalis). Zakażenie jabłek w okresie przedzbiorczym skutkuje rozwojem plam parcha na powierzchni owoców podczas przechowywania. Ochronę jabłek przed parchem przechowalniczym prowadzi się w ostatnich tygodniach przed zbiorem, a jednym $\mathrm{z}$ rekomendowanych fungicydów był Thiram Granuflo 80 WG (PORS 2010).

Celem badań było określenie wpływu liczby i terminów zabiegów fungicydami Captan 80 WG i Thiram Granuflo 80 WG na poziom pozostałości substancji czynnych tych fungicydów w jabłkach bezpośrednio po zbiorze i po przechowywaniu. Poziom pozostałości badanych substancji czynnych analizowano pod kątem spełnienia wymagań norm unijnych i obowiązujących w Federacji Rosyjskiej, do której polskie jabłka są często wysyłane oraz norm dla niemowląt i małych dzieci. Oceniono także skuteczność działania tych fungicydów stosowanych w różnych programach, w zwalczaniu gorzkiej zgnilizny jabłek i parcha przechowalniczego.

\section{Materiały i metody / Materials and methods}

Badania prowadzono w ciagu 2 sezonów przechowalniczych 2010/2011 i 2011/2012, w dwóch sadach prowadzonych systemem Integrowanej Produkcji Owoców (IPO). Przedmiotem badań były fungicydy Captan $80 \mathrm{WG}$ (80\% kaptanu) i Thiram Granuflo 80 WG (80\% tiuramu). W obu sadach prowadzono standardową ochronę drzew przed chorobami (głównie parchem jabłoni) według zaleceń Programu Ochrony Roślin Sadowniczych (PORS), którą zakończono 1,5 miesiąca przed zbiorem. W sadzie, w Ostrowcu koło Łowicza, 8-letnie drzewa odmiany Szampion opryskiwano przed zbiorem preparatem Captan $80 \mathrm{WG}$ w zalecanej dawce $1,9 \mathrm{~kg} / \mathrm{ha}$. Zastosowano 11 programów zwalczania (tab. 1), w których wykonywano od 1 do 4 zabiegów w różnych kombinacjach terminów (28, 21, 14, 7 dni przed zbiorem). Kombinację kontrolną (Program I) stanowiły drzewa nieopryskiwane w tych terminach żadnymi fungicydami. Każda kombinacja obejmowała w układzie pasowym 20 kolejnych drzew (4 powtórzenia po 5 drzew). W Sadzie Doświadczalnym Instytutu Ogrodnictwa w Dąbrowicach doświadczenie założono na 10-letnich drzewach odmiany Jonagored. Preparat Thiram Granuflo $80 \mathrm{WG}$, w dawce 3,0 kg/ha stosowano przeciwko parchowi przechowalniczemu w 4 programach (tab. 3), w których wykonywano zabiegi $\mathrm{w}$ terminach 14 i 7 dni przed zbiorem. Kombinacje kontrolną (Program I) stanowiły drzewa nieopryskiwane w tych terminach. Każda kombinacja doświadczalna obejmowała 20 drzew (4 powtórzenia po 5 drzew). Owoce $\mathrm{z}$ obu sadów zbierano $\mathrm{w}$ stanie dojrzałości zbiorczej wyznaczonej na podstawie próby skrobiowej. Z każdego powtórzenia pobrano losowo 10 jabłek (40 owoców z kombinacji doświadczalnej), z których wydzielono reprezentatywną próbkę do przeprowadzenia analizy pozostałości kaptanu (jabłka odmiany Szampion) i tiuramu (jabłka odmiany Jonagored) bezpośrednio po zbiorze. Zebrane owoce obu odmian, po 6 uniwersalnych skrzynek z kombinacji (100 szt. owoców w każdej), przewieziono do chłodni doświadczalnej Instytutu Ogrodnictwa w Skierniewicach, gdzie je przechowywano w warunkach atmosfery normalnej, w temperaturze $2{ }^{\circ} \mathrm{C}$ i wilgotności względnej powietrza $>90 \%$. Po zakończeniu przechowywania (6 miesięcy) pobrano losowo próbki jabłek (10 sztuk w czterech powtórzeniach) do ponownej analizy pozostałości badanych fungicydów oraz przeprowadzono ocenę występowania chorób grzybowych, licząc w każdej skrzynce owoce zdrowe i z objawami gorzkiej zgnilizny jabłek i parcha przechowalniczego.

Pozostałości kaptanu oznaczano przy użyciu chromatografu gazowego (Agilent Technologies 6890N Network GC System) wyposażonego w detektor masowy (Agilent Technologies 5975B inert XL Mass Selectivity Detector) i komorę nastrzykową typu PTV, po uprzedniej ekstrakcji z próbki acetonitrylem oraz oczyszczaniu metodą dyspersyjnej SPE (Solid Phase Extraction) - metoda QuEChERS (Quick, Eeasy, Cheap, Effective, Rugged and Safe) (Anastassiades i wsp. 2003; PN-EN 2008). Rozdział substancji przeprowadzono na kolumnie kapilarnej DB5MS, 30,0 $\mathrm{m} \times 250 \mu \mathrm{m} \times 0,25 \mu \mathrm{m}$. Metoda oznaczania kaptanu została zwalidowana (SANCO 2009, 2011) i jest 
akredytowana przez Polskie Centrum Akredytacji $(\mathrm{Nr}$ akredytacji - AB 757). Dolna granica oznaczalności dla kaptanu została określona na poziomie $0,01 \mathrm{mg} / \mathrm{kg}$, odzysk dla próbek wzbogaconych wynosił 96\%, przy względnym odchyleniu standardowym - 5\%. Niepewność rozszerzona wyników pomiaru została oszacowana na poziomie $15,8 \%$.

Pozostałości tiuramu oznaczano metodą opartą na pomiarze disiarczku węgla $\left(\mathrm{CS}_{2}\right)$ uwolnionego $\mathrm{z}$ tkanki roślinnej podczas ogrzewania $\mathrm{w}$ gazoszczelnym naczyniu z kwasem chlorowodorowym i chlorkiem cyny (II), a następnie zaadsorbowaniu gazowego $\mathrm{CS}_{2}$ do fazy ciekłejizooktanowej i ilościowym oznaczeniu za pomocą chromatografu gazowego (PN-EN 2002; Česnik i Gregorčič 2006). Analizę próbki przeprowadzono przy użyciu chromatografu gazowego Agilent Technologies 6850 Series GC System wyposażonego w detektor masowy: 5973N Mass Selectivity Detektor i autosampler 6850 Automatic Liquid Sampler. Rozdział substancji przeprowadzono na kolumnie kapilarnej DB-35MS, 30,0 $\mathrm{m} \times 250 \mu \mathrm{m} \times 0,25 \mu \mathrm{m}$. Metoda oznaczania $\mathrm{CS}_{2}$ została zwalidowana (SANCO 2009, 2011) i jest akredytowana przez Polskie Centrum Akredytacji (Nr akredytacji - AB 757). Dolną granicę oznaczalności dla tej metody określono na poziomie 0,05 $\mathrm{mg} / \mathrm{kg}$. Odzysk dla próbek wzbogaconych wynosił 104\%, względne odchylenie standardowe - 10\%, a niepewność rozszerzona $-28 \%$.

Wyniki pozostałości badanych środków ochrony roślin oraz nasilenia chorób grzybowych opracowano statystycznie stosując metodę analizy wariancji R.A. Fischera. Wartości procentowe nasilenia chorób przekształcano według transformacji Blissa. Do oceny różnic między średnimi użyto testu Newmana-Keulsa, przyjmując poziom istotności $5 \%$.

\section{Wyniki i dyskusja / Results and discussion}

Wyniki badań wskazują, że sezon wegetacyjny istotnie wpływa na poziom pozostałości kaptanu w jabłkach. Mimo zastosowania takich samych programów ochrony w sezonie 2010/2011 stwierdzono wyższą zawartość kaptanu w owocach, tak po zbiorze, jak i po przechowywaniu, w porównaniu do sezonu 2011/2012. W sezonie 2010/2011 po 4-krotnym zastosowaniu preparatu Captan 80 WG w odstępach tygodniowych przed zbiorem (Program II) średnia zawartość kaptanu w owocach bezpośrednio po zbiorze przekraczała najwyższy dopuszczalny poziom (NDP) wymagany w Unii Europejskiej (UE) i Federacji Rosyjskiej (FR) - 3 mg/kg. Rozkład kaptanu w owocach, w czasie przechowywania był na tyle niski, że jabłka z tej kombinacji również po przechowywaniu nie spełniały norm dla pozostałości kaptanu w UE i FR (tab. 1). W przypadku wykonania 3 zabiegów (Program III i IV), jabłka w czasie zbioru miały także przekroczone wartości NDP, przy czym większą ilość kaptanu stwierdzono wtedy, gdy terminy zabiegów były bliżej zbioru. Po przechowaniu tych jabłek zawartość kaptanu obniżyła się do bezpiecznego poziomu, tzn. poniżej $3 \mathrm{mg} / \mathrm{kg}$. W owocach z pozostałych Programów (V-XI) poziom pozostałości kaptanu w czasie zbioru był poniżej NDP wymaganych w UE i FR. Po 6 miesiącach przechowywania jabłek w chłodni zwykłej poziom pozostałości kaptanu obniżył się w różnym stopniu, w zależności od zastosowanego programu i tylko owoce z Programu II miały nadal przekroczony dopuszczalny poziom pozostałości kaptanu. W sezonie 2011/2012 poziom pozostałości kaptanu w owocach również zależał od zastosowanego programu ochrony (tab. 1). Utrzymywały się podobne zależności, jak w sezonie 2010/2011, przy czym zawartość kaptanu w owocach ze wszystkich badanych kombinacji doświadczalnych, bezpośrednio po zbiorze, jak i po przechowywaniu była znacznie niższa niż w sezonie 2010/2011 i nie przekraczała najwyższego dopuszczalnego poziomu.

Po zakończonym przechowywaniu jabłek stwierdzono, że nasilenie gorzkiej zgnilizny na owocach odmiany Szampion było $\mathrm{w}$ obu sezonach na średnim poziomie, jednak stwierdzono istotne różnice w efektywności zastosowanych programów ochrony (tab. 2). W sezonie 2010/2011 najwyższą skuteczność (około 93\%) stwierdzono po trzykrotnym zastosowaniu środka Captan $80 \mathrm{WG}$ w terminach 28, 21 i 14 dni (Program III) oraz 2-krotnym (około 85\%) w terminach 21 i 14 dni (Program VI). Ta ostatnia kombinacja wydaje się być optymalną ze względu na bezpieczny poziom pozostałości kaptanu w jabłkach oraz bardzo dobrą skuteczność zwalczania gorzkiej zgnilizny jabłek. Dla tej kombinacji doświadczalnej również W sezonie 2011/2012 stwierdzono najwyższą skuteczność w zwalczaniu gorzkiej zgnilizny jabłek (około 98\%). Najmniej skuteczne było jednorazowe stosowanie preparatu w terminach 28, 14 lub 7 dni przed zbiorem.

W przypadku owoców odmiany Jonagored traktowanych preparatem Thiram Granuflo $80 \mathrm{WG}$, niezależnie od liczby i terminów zabiegów, pozostałości $\mathrm{CS}_{2}$ (tab. 3) w obu sezonach badań, zawierały się poniżej NDP wymaganego w UE i FR (5 mg/kg). Największy wpływ na poziom pozostałości ditiokarbaminianów w owocach miał termin wykonania zabiegów. Wyższe zawartości $\mathrm{CS}_{2}$ stwierdzono $w$ owocach traktowanych dwukrotnie preparatem Thiram Granuflo 80 WG w terminach 14 i 7 dni przed zbiorem, w porównaniu do jednorazowej aplikacji środka (tab. 3). Po 6-miesięcznym okresie przechowywania poziom pozostałości $\mathrm{CS}_{2} \mathrm{w}$ jabłkach ze wszystkich badanych programów zmniejszył się.

Nasilenie chorób przechowalniczych, zarówno parcha przechowalniczego, jak i gorzkiej zgnilizny, na jabłkach odmiany Jonagored było większe w sezonie 2010/2011 niż W sezonie 2011/2012. W pierwszym sezonie badań Thiram Granuflo 80 WG zastosowany dwukrotnie przed zbiorem (Program II) wykazał najwyższą skuteczność ochrony owoców przed obiema chorobami, natomiast zastosowany jednorazowo w terminie 14 dni przed zbiorem istotnie ograniczył tylko nasilenie gorzkiej zgnilizny jabłek (tab. 4). W drugim sezonie badań, przy znacznie mniejszym nasileniu obu chorób, wszystkie zastosowane programy ochrony istotnie ograniczyły nasilenie obu chorób, jakkolwiek nie stwierdzono istotnych różnic w efektywności poszczególnych programów (tab. 5).

Dotychczasowe badania nad zanikaniem pozostałości kaptanu i ditiokarbaminianów w owocach prowadzone były w większości podczas wzrostu jabłek na drzewie (Szpyrka i wsp. 2009, 2011), a nieliczne po przechowaniu owoców (Bryk i wsp. 2005; Sadło i Walorczyk 2011). 
Rozkład pestycydów zachodzi znacznie szybciej w owocach rosnących, niż w owocach przechowywanych, a tempo rozkładu zależy od rodzaju pestycydu i warunków przechowywania owoców (Bryk i wsp. 2005). W prezentowanych obecnie badaniach analizowano zanik pozostałości fungicydów w jabłkach, w czasie 6-miesięcznego

Tabela 1. Poziom pozostałości kaptanu w jabłkach odmiany Szampion, po zbiorze i po przechowywaniu, w zależności od liczby i terminów zabiegów przed zbiorem owoców preparatem Captan 80 WG

Table 1. Captan residues in apples cultivar Sampion after harvest and after cold storage depending on the number and dates of Captan $80 \mathrm{WG}$ treatments

\begin{tabular}{|c|c|c|c|c|c|c|}
\hline \multirow{3}{*}{$\begin{array}{l}\text { Program } \\
\text { Program }\end{array}$} & \multirow{3}{*}{$\begin{array}{c}\text { Liczba } \\
\text { zabiegów } \\
\text { The number } \\
\text { of treatments }\end{array}$} & \multirow{3}{*}{$\begin{array}{c}\text { Terminy zabiegów } \\
\text { (dni przed zbiorem) } \\
\text { Dates of treatments } \\
\text { (days before } \\
\text { harvest) }\end{array}$} & \multicolumn{4}{|c|}{$\begin{array}{l}\text { Pozostałości kaptanu - Captan residues } \\
\qquad[\mathrm{mg} / \mathrm{kg}]\end{array}$} \\
\hline & & & \multicolumn{2}{|c|}{$\begin{array}{l}\text { sezon } 2010 / 2011 \\
\text { season } 2010 / 2011\end{array}$} & \multicolumn{2}{|c|}{$\begin{array}{c}\text { sezon } 2011 / 2012 \\
\text { season } 2011 / 2012\end{array}$} \\
\hline & & & $\begin{array}{l}\text { po zbiorze } \\
\text { after harvest }\end{array}$ & $\begin{array}{l}\text { po przechowaniu } \\
\text { after storage }\end{array}$ & $\begin{array}{l}\text { po zbiorze } \\
\text { after harvest }\end{array}$ & $\begin{array}{l}\text { po przechowaniu } \\
\text { after storage }\end{array}$ \\
\hline I & 0 & - & $0,18 \mathrm{a}$ & $0,11 \mathrm{a}$ & $0,21 \mathrm{ab}$ & $0,08 \mathrm{a}$ \\
\hline II & 4 & $28,21,14,7$ & $3,89 \mathrm{f}$ & $3,45 \mathrm{f}$ & $2,55 \mathrm{f}$ & $1,20 \mathrm{f}$ \\
\hline III & 3 & $28,21,14$ & $3,04 \mathrm{e}$ & $2,39 \mathrm{e}$ & $1,76 \mathrm{e}$ & $0,72 \mathrm{e}$ \\
\hline IV & 3 & $28,14,7$ & $3,73 \mathrm{f}$ & $2,67 \mathrm{e}$ & $1,81 \mathrm{e}$ & $0,60 \mathrm{de}$ \\
\hline $\mathrm{V}$ & 2 & 28,21 & $1,15 \mathrm{c}$ & $1,01 \mathrm{bc}$ & $0,50 \mathrm{abc}$ & $0,30 \mathrm{bc}$ \\
\hline VI & 2 & 21,14 & $2,40 \mathrm{de}$ & $1,52 \mathrm{c}$ & $0,80 \mathrm{~cd}$ & $0,42 \mathrm{~cd}$ \\
\hline VII & 2 & 14,7 & $2,68 \mathrm{de}$ & $1,33 \mathrm{c}$ & $1,17 \mathrm{~d}$ & $0,57 \mathrm{de}$ \\
\hline VIII & 1 & 28 & $0,53 \mathrm{ab}$ & $0,41 \mathrm{ab}$ & $0,24 \mathrm{ab}$ & $0,18 \mathrm{ab}$ \\
\hline IX & 1 & 21 & $0,72 \mathrm{bc}$ & $0,31 \mathrm{ab}$ & $0,44 a b c$ & $0,30 \mathrm{bc}$ \\
\hline $\mathrm{X}$ & 1 & 14 & $2,06 \mathrm{~d}$ & $0,97 \mathrm{bc}$ & $0,76 \mathrm{bcd}$ & $0,58 \mathrm{de}$ \\
\hline XI & 1 & 7 & $2,20 \mathrm{~d}$ & $0,80 \mathrm{~b}$ & $0,94 \mathrm{~cd}$ & $0,69 \mathrm{e}$ \\
\hline
\end{tabular}

Analiza statystyczna przeprowadzona oddzielnie dla każdego sezonu i terminu. Średnie oznaczone w kolumnach tą samą literą nie różnią się istotnie według testu Newmana-Keulsa przy $\mathrm{p}=0,05$

Statistical analysis was performed separately for each season and date. Means followed in columns by the same letter do not differ significantly at $5 \%$ level by Newman-Keuls test

Tabela 2. Efektywność preparatu Captan 80 WG w zwalczaniu gorzkiej zgnilizny jabłek w zależności od liczby i terminów zabiegów przed zbiorem

Table 2. Effectiveness of Captan $80 \mathrm{WG}$ in the control of bull's eye rot depending on the number and dates of treatments before harvest

\begin{tabular}{|c|c|c|c|c|c|c|}
\hline \multirow[b]{2}{*}{$\begin{array}{l}\text { Program } \\
\text { Program }\end{array}$} & \multirow[b]{2}{*}{$\begin{array}{l}\text { Liczba } \\
\text { zabiegów } \\
\text { The number } \\
\text { treatments }\end{array}$} & \multirow{2}{*}{\begin{tabular}{|} 
Terminy zabiegów \\
(dni przed \\
zbiorem) \\
Dates \\
of treatments \\
(days before \\
harvest)
\end{tabular}} & \multicolumn{2}{|c|}{$\begin{array}{c}\text { Sezon } 2010 / 2011 \\
\text { Season } 2010 / 2011\end{array}$} & \multicolumn{2}{|c|}{$\begin{array}{c}\text { Sezon } 2011 / 2012 \\
\text { Season } 2011 / 2012\end{array}$} \\
\hline & & & $\begin{array}{c}\% \text { jabłek } \\
\text { z objawami gorzkiej } \\
\text { zgnilizny } \\
\text { percent of apples } \\
\text { infected } \\
\text { by Pezicula spp. }\end{array}$ & $\begin{array}{c}\text { efektywność } \\
\text { programu } \\
\text { effectiveness } \\
\text { of program } \\
{[\%]}\end{array}$ & $\begin{array}{l}\% \text { jabłek z objawami } \\
\text { gorzkiej zgnilizny } \\
\text { percent of apples } \\
\text { infected } \\
\text { by Pezicula spp. }\end{array}$ & $\begin{array}{c}\text { efektywność } \\
\text { programu } \\
\text { effectiveness } \\
\text { of program } \\
{[\%]}\end{array}$ \\
\hline I & 0 & - & $5,51 \mathrm{c}$ & - & $6,24 \mathrm{c}$ & - \\
\hline II & 4 & $28,21,14,7$ & $1,71 \mathrm{ab}$ & 69,0 & $1,37 \mathrm{ab}$ & 78,0 \\
\hline III & 3 & $28,21,14$ & $0,41 \mathrm{a}$ & 92,6 & $1,45 \mathrm{ab}$ & 76,8 \\
\hline IV & 3 & $28,14,7$ & $1,98 a b c$ & 64,1 & $1,29 \mathrm{ab}$ & 79,3 \\
\hline $\mathrm{V}$ & 2 & 28,21 & $1,69 \mathrm{ab}$ & 69,3 & $2,28 \mathrm{~b}$ & 63,5 \\
\hline VI & 2 & 21,14 & $0,84 \mathrm{ab}$ & 84,8 & $0,12 \mathrm{a}$ & 98,1 \\
\hline VII & 2 & 14,7 & $2,26 \mathrm{abc}$ & 59,0 & $0,36 \mathrm{ab}$ & 94,2 \\
\hline VIII & 1 & 28 & $3,73 \mathrm{bc}$ & 32,3 & $2,83 \mathrm{~b}$ & 54,6 \\
\hline IX & 1 & 21 & $3,29 \mathrm{bc}$ & 40,3 & $0,88 \mathrm{ab}$ & 85,9 \\
\hline $\mathrm{X}$ & 1 & 14 & $1,66 \mathrm{ab}$ & 69,9 & $2,05 \mathrm{ab}$ & 67,1 \\
\hline XI & 1 & 7 & $2,90 \mathrm{bc}$ & 47,4 & $2,58 \mathrm{~b}$ & 58,7 \\
\hline
\end{tabular}

Analiza statystyczna przeprowadzona oddzielnie dla każdego sezonu. Średnie oznaczone tą samą literą nie różnią się istotnie według testu NewmanaKeulsa przy $\mathrm{p}=0,05$

Statistical analysis was performed separately for each season. Means followed by the same letter do not differ significantly at $5 \%$ level by NewmanKeuls test 
Tabela 3. Poziom pozostałości $\mathrm{CS}_{2} \mathrm{w}$ jabłkach odmiany Jonagored, bezpośrednio po zbiorze i po przechowywaniu jabłek, w zależności od liczby i terminów zabiegów przed zbiorem preparatem Thiram Granuflo $80 \mathrm{WG}$

Table 3. $\mathrm{CS}_{2}$ residues in apples cultivar Jonagored after harvest and after cold storage depending on the number and dates of Thiram Granuflo 80 WG treatments

\begin{tabular}{|c|c|c|c|c|c|c|}
\hline \multirow{3}{*}{$\begin{array}{l}\text { Program } \\
\text { Program }\end{array}$} & \multirow{3}{*}{$\begin{array}{c}\text { Liczba zabiegów } \\
\text { The number } \\
\text { of treatments }\end{array}$} & \multirow{3}{*}{$\begin{array}{c}\text { Terminy zabiegów } \\
\text { (dni przed zbiorem) } \\
\text { Dates } \\
\text { of treatments } \\
\text { (days before } \\
\text { harvest) }\end{array}$} & \multicolumn{4}{|c|}{$\begin{array}{c}\text { Pozostałości } \mathrm{CS}_{2}-\mathrm{CS}_{2} \text { residues } \\
{[\mathrm{mg} / \mathrm{kg}]}\end{array}$} \\
\hline & & & \multicolumn{2}{|c|}{$\begin{array}{l}\text { sezon } 2010 / 2011 \\
\text { season } 2010 / 2011 \\
\end{array}$} & \multicolumn{2}{|c|}{$\begin{array}{c}\text { sezon } 2011 / 2012 \\
\text { season } 2011 / 2012\end{array}$} \\
\hline & & & $\begin{array}{l}\text { po zbiorze } \\
\text { after harvest }\end{array}$ & $\begin{array}{l}\text { po przechowaniu } \\
\text { after storage }\end{array}$ & $\begin{array}{l}\text { po zbiorze } \\
\text { after harvest }\end{array}$ & $\begin{array}{l}\text { po przechowaniu } \\
\text { after storage }\end{array}$ \\
\hline I & 0 & - & $0,023 \mathrm{a}$ & n.w. & $0,073 \mathrm{a}$ & $0,055 \mathrm{a}$ \\
\hline II & 4 & 14,7 & $0,43 \mathrm{c}$ & $0,13 \mathrm{~b}$ & $0,64 \mathrm{c}$ & $0,53 \mathrm{c}$ \\
\hline III & 3 & 14 & $0,097 \mathrm{~b}$ & $0,014 \mathrm{a}$ & $0,24 \mathrm{~b}$ & $0,17 \mathrm{~b}$ \\
\hline IV & 3 & 7 & $0,36 \mathrm{c}$ & $0,088 \mathrm{~b}$ & $0,53 \mathrm{c}$ & $0,27 \mathrm{~b}$ \\
\hline
\end{tabular}

Analiza statystyczna przeprowadzona oddzielnie dla każdego sezonu i terminu. Średnie oznaczone w kolumnach ta sama litera nie różnią sie istotnie według testu Newmana-Keulsa przy $\mathrm{p}=0,05$

Statistical analysis was performed separately for each season and term. Means followed in columns by the same letter do not differ significantly at $5 \%$ level by Newman-Keuls test

n.w. - nie wykryto - not detected

Tabela 4. Efektywność preparatu Thiram Granuflo 80 WG w zwalczaniu parcha przechowalniczego i gorzkiej zgnilizny jabłek w zależności od liczby i terminów zabiegów przed zbiorem - sezon 2010/2011

Table 4. Effectiveness of Thiram Granuflo $80 \mathrm{WG}$ in the control of bull's eye rot depending on the number and dates of treatments before harvest - season 2010/2011

\begin{tabular}{c|c|c|c|c|c|c}
\hline \multirow{2}{*}{$\begin{array}{c}\text { Program } \\
\text { Program }\end{array}$} & $\begin{array}{c}\text { Liczba zabiegów } \\
\text { The number } \\
\text { of treatments }\end{array}$ & $\begin{array}{c}\text { Terminy zabiegów } \\
\text { (dni przed } \\
\text { zbiorem) } \\
\text { Dates } \\
\text { of treatments } \\
\text { (days before } \\
\text { harvest) }\end{array}$ & $\begin{array}{c}\text { \% jabłek } \\
\text { z objawami parcha } \\
\text { przechowalniczego } \\
\text { Percent of apples } \\
\text { infected by } \\
\text { V. inaequalis }\end{array}$ & $\begin{array}{c}\text { Efektywność } \\
\text { programu } \\
\text { Effectiveness } \\
\text { of program } \\
{[\%]}\end{array}$ & $\begin{array}{c}\text { \% jabłek } \\
\text { z objawami } \\
\text { gorzkiej zgnilizny } \\
\text { Percent of apples } \\
\text { infected by } \\
\text { Pezicula spp. }\end{array}$ & $\begin{array}{c}\text { Efektywność } \\
\text { programu } \\
\text { Effectiveness } \\
\text { of program } \\
{[\%]}\end{array}$ \\
\hline I & 0 & - & $36,84 \mathrm{~b}$ & - & $10,19 \mathrm{c}$ & - \\
II & 2 & 14,7 & $7,93 \mathrm{a}$ & 78,5 & $0,76 \mathrm{a}$ & 92,5 \\
III & 1 & 14 & $24,45 \mathrm{~b}$ & 33,6 & $3,56 \mathrm{~b}$ & 65,1 \\
IV & 1 & 7 & $25,83 \mathrm{~b}$ & 30,0 & $7,10 \mathrm{bc}$ & 30,3 \\
\hline
\end{tabular}

Analiza statystyczna przeprowadzona oddzielnie dla każdego sezonu i choroby. Średnie oznaczone tą samą literą nie różnią się istotnie według testu Newmana-Keulsa przy $\mathrm{p}=0,05$

Statistical analysis was performed separately for each season and disease. Means followed by the same letter do not differ significantly at $5 \%$ level by Newman-Keuls test

Tabela 5. Efektywność preparatu Thiram Granuflo 80 WG w zwalczaniu parcha przechowalniczego i gorzkiej zgnilizny jabłek w zależności od liczby i terminów zabiegów przed zbiorem - sezon 2011/2012

Table 5. Effectiveness of Thiram Granuflo $80 \mathrm{WG}$ in the control of bull's eye rot depending on the number and dates of treatments before harvest - season 2011/2012

\begin{tabular}{|c|c|c|c|c|c|c|}
\hline $\begin{array}{l}\text { Program } \\
\text { Program }\end{array}$ & $\begin{array}{c}\text { Liczba } \\
\text { zabiegów } \\
\text { The number } \\
\text { of treatments }\end{array}$ & \begin{tabular}{|} 
Terminy zabiegów \\
(dni przed \\
zbiorem) \\
Dates \\
of treatments \\
(days before \\
harvest)
\end{tabular} & $\begin{array}{c}\text { \% jabłek } \\
\text { z objawami parcha } \\
\text { przechowalniczego } \\
\text { Percent of apples } \\
\text { infected by } \\
\text { V. inaequalis }\end{array}$ & $\begin{array}{c}\text { Efektywność } \\
\text { programu } \\
\text { Effectiveness } \\
\text { of program } \\
{[\%]}\end{array}$ & $\begin{array}{c}\% \text { jabłek z objawami } \\
\text { gorzkiej zgnilizny } \\
\text { Percent of apples } \\
\text { infected by } \\
\text { Pezicula spp. }\end{array}$ & $\begin{array}{c}\text { Efektywność } \\
\text { programu } \\
\text { Effectiveness } \\
\text { of program } \\
{[\%]}\end{array}$ \\
\hline I & 0 & - & $10,62 \mathrm{~b}$ & - & $3,03 \mathrm{~b}$ & - \\
\hline II & 2 & 14,7 & $4,33 \mathrm{a}$ & 59,2 & $0,30 \mathrm{a}$ & 90,1 \\
\hline III & 1 & 14 & $4,24 \mathrm{a}$ & 60,1 & $0,73 \mathrm{a}$ & 75,9 \\
\hline IV & 1 & 7 & $4,67 \mathrm{a}$ & 56,0 & $0,77 \mathrm{a}$ & 75,6 \\
\hline
\end{tabular}

Analiza statystyczna przeprowadzona oddzielnie dla każdego sezonu i choroby. Średnie oznaczone tą samą literą nie różnią się istotnie według testu Newmana-Keulsa przy $\mathrm{p}=0,05$

Statistical analysis was performed separately for each season and disease. Means followed by the same letter do not differ significantly at $5 \%$ level by Newman-Keuls test 
przechowywania w chłodni zwykłej. Stwierdzono, że im większy początkowy (wyjściowy) poziom pozostałości, tym rozkład wolniejszy. Średnio ze wszystkich kombinacji doświadczalnych poziom pozostałości kaptanu w obu sezonach zmniejszył się odpowiednio o 33,7 i 53,7\%, a $\mathrm{CS}_{2}$ o 74,8 i $30,8 \%$. Po zakończonym przechowywaniu jabłek pozostałości badanych fungicydów kształtowały się na różnym poziomie, w zależności od zastosowanego programu ochrony, jednak nadal były zbyt wysokie, aby owoce mogły być wykorzystane do produkcji odżywek dla niemowląt i małych dzieci (powyżej normy $0,01 \mathrm{mg} / \mathrm{kg}$ ). Jabłka przeznaczone na przetwory dla dzieci powinny być uprawiane i chronione w specjalny sposób, co potwierdzili również inni autorzy (Sadło i Walorczyk 2011; Szpyrka i wsp. 2011).

\section{Wnioski / Conclusions}

1. Dwukrotne zastosowanie preparatu Captan $80 \mathrm{WG}$ w terminach 21 i 14 dni przed zbiorem nie powodowało przekroczenia norm NDP (w UE i FR) dla pozostałości kaptanu w jabłkach, w czasie zbioru i po przechowaniu oraz skutecznie ograniczyło wystapienie gorzkiej zgnilizny jabłek.

2. Czterokrotne użycie preparatu Captan $80 \mathrm{WG}$ przed zbiorem (w terminach 28, 21, 14 i 7 dni) powodowało przekroczenie lub było bliskie normie NDP dla pozostałości kaptanu w jabłkach, w czasie zbioru.

3. Dwukrotne zastosowanie preparatu Thiram Granuflo
80 WG w terminach 14 i 7 dni przed zbiorem było bardziej skuteczne w zwalczaniu parcha przechowalniczego i gorzkiej zgnilizny jabłek od jednorazowego zastosowania środka. Zarówno dwukrotne, jak i jednorazowe użycie środka nie powodowało przekroczenia norm na zawartość $\mathrm{CS}_{2}$ w jabłkach, w czasie zbioru i po przechowaniu.

4. W czasie przechowywania owoców, w warunkach chłodni zwykłej, następował powolny rozkład fungicydów, a tempo rozkładu zależało od początkowej zawartości fungicydu.

5. Jabłka przeznaczone na przetwory dla niemowląt i małych dzieci powinny być uprawiane i chronione w specjalny sposób, ponieważ nawet jednorazowe zastosowanie badanych preparatów przed zbiorem powodowało obecność substancji czynnych powyżej dopuszczalnych norm.

\section{Uwaga / Note}

1. Ze względu na zmianę etykiety rejestracyjnej preparatu Captan 80 WG nie może on być stosowany od 2014 roku do ochrony jabłek przed gorzką zgnilizna, a przed parchem przechowalniczym nie później, jak 28 dni przed zbiorem.

2. Ze względu na zmianę etykiety rejestracyjnej preparatu Thiram Granuflo 80 WG nie może on być stosowany później niż 35 dni przed zbiorem jabłek.

\section{Literatura / References}

Anastassiades M., Lehotay S.J., Stajnbaher D., Schenck F.J. 2003. Fast and easy multiresidue method employing acetonitrile extraction/partitioning and 'dispersive solid-phase extraction' for the determination of pesticide residues in produce. J. AOAC Int. 86 (2): 412-431.

Bryk H. 2003. Efektywnosć kaptanu w zwalczaniu gorzkiej zgnilizny jabłek (Pezicula spp.). Zesz. Nauk. Inst. Sadownictwa i Kwiaciarstwa 11: 35-40.

Bryk H. 2010. Choroby przechowalnicze jabłek i gruszek. s. 17-26. W: VI Międzynarodowe Targi Agrotechniki Sadowniczej. Warszawa, 15-16.01.2010, 162 ss.

Bryk H., Miszczak A., Nowacki J. 2005. Dynamika zanikania wybranych fungicydów w jabłkach podczas przechowywania w zależności od sposobu aplikacji. [The dynamics of fungicides degradation in stored apples depending on the method of application]. Prog. Plant Prot./Post. Ochr. Roślin 45 (2): 593-596.

Česnik H.B., Gregorčič A. 2006. Validation of the method for the determination of dithiocarbamates and thiuram disulphide on apple, lettuce, potato, strawberry and tomato matrix. Acta Chim. Slov. 53: 100-104.

Neri F., Mari M., Brigati S., Bertolini P. 2009. Control of Neofabrea alba by plant volatile compounds and hot water. Postharvest Biol. Techn. 51: 425-430.

Nowacka A., Gnusowski B. 2009. Bezpieczeństwo zdrowotne polskich płodów rolnych w aspekcie pozostałości środków ochrony roślin stosowanych do ich ochrony. [Estimation of dietary exposure to pesticide residues in Polish crops in 2008]. Prog. Plant Prot./Post. Ochr. Roślin 49 (4): 1895-1902.

Nowacka A., Gnusowski B., Raczkowski M. 2012. Bezpieczeństwo zdrowotne polskich płodów rolnych w 2010 roku związane z pozostałościami środków ochrony roślin. [Estimation of dietary exposure to pesticide residues in Polish crops in 2010]. Prog. Plant Prot./Post. Ochr. Roślin 52 (1): 141-145.

PN-EN 12396-2. 2002. Żywność o niskiej zawartości tłuszczu - Oznaczanie pozostałości ditiokarbaminianów i disiarczku tiuramu. Część 2: Metoda z wykorzystaniem chromatografii gazowej, 9 ss.

PN-EN 15662. 2008. Żywność pochodzenia roślinnego. Oznaczanie pozostałości pestycydów metodą GC-MS i/lub LC-MS(MS) po uprzedniej ekstrakcji i rozdziale acetonitrylem oraz oczyszczaniu metodą dyspersyjną SPE. Metoda QuEChERS, $81 \mathrm{ss.}$

PORS - Program Ochrony Roślin Sadowniczych. 2010. Hortpress Sp. z o.o., Warszawa, 172 ss.

Rozporządzenie (WE) nr 396/2005 Parlamentu Europejskiego i Rady z dnia 23 lutego 2005 r. w sprawie najwyższych dopuszczalnych poziomów pozostałości pestycydów w żywności i paszy pochodzenia roślinnego i zwierzęcego oraz na ich powierzchni, zmieniające dyrektywę Rady 91/414/EWG (Dz. Urz. L 70 z 16.03.2006 r. z późn. zm.). 
Rozporządzenie Ministra Zdrowia z dnia 16 maja 2007 r. w sprawie najwyższych dopuszczalnych poziomów pozostałości pestycydów, które mogą znajdować się w środkach spożywczych lub na ich powierzchni (Dz. U. z 2008 r. Nr 119, poz. 817 z późn. zm.).

Rozporządzenie Ministra Rolnictwa i Rozwoju Wsi z dnia 28 maja 2008 r. zmieniające rozporządzenie w sprawie wykazu substancji aktywnych, których stosowanie w środkach ochrony roślin jest zabronione (Dz. U. z 2008 r. Nr 95, poz. 605).

Sadło S., Walorczyk S. 2011. Pozostałości wybranych fungicydów w dojrzałych jabłkach oraz ich zmiany bezpośrednio po zabiegu i podczas przechowywania owoców. [Residues of selected fungicides in ripe apples and trends in their changes immediately after the treatments and during fruit storage]. Prog. Plant Prot./Post. Ochr. Roślin 51 (2): 732-736.

SANCO. 2009. Method validation and quality control procedures for pesticide residues analysis in food and feed. Document No SANCO/10684/2009. Supersedes Document No SANCO/3131/2007, 53 pp.

SANCO. 2011. Method validation and quality control procedures for pesticide residues analysis in food and feed. Document No SANCO/12495/2011. Supersedes Document No SANCO/10684/2009, 40 pp.

Szpyrka E., Rogozińska K., Rupar J., Słowik-Borowiec M., Grzegorzak M., Kurdziel A. 2011. Zanikanie pozostałości ditiokarbaminianów stosowanych w sadach jabłoniowych przeciwko chorobom grzybowym. [Decay of residues of dithiocarbamates applied in apple orchards against fungal disease agents]. Prog. Plant Prot./Post. Ochr. Roślin 51 (1): 387-389.

Szpyrka E., Sadło S., Słowik-Borowiec M. 2009. Zanikanie kaptanu i propikonazolu w owocach i liściach jabłoni odmiany Jonagold. [Disappearance of captan and propiconazole in fruits and leaves of Jonagold apple]. Prog. Plant Prot./Post. Ochr. Roślin 49 (3): $1447-1451$.

Ustawa z dnia 25 sierpnia 2006 r. o bezpieczeństwie żywności i żywienia (Dz. U. z 2006 r. Nr 171, poz. 1225 z późn. zm.).

Weber R. 2009. Apple storage rots: the situation in Northern Germany. p. 1-2. In: COST 864 Expert Meeting. Norway, Bergen, March 25-26, 2009, $32 \mathrm{pp}$. 